\title{
TEM Investigation of Precipitation in Al-Mn Alloys with Addition of $\mathbf{Z r}$
}

Michaela Poková ${ }^{1,2}$, Miroslav Cieslar ${ }^{1}$, Jacques Lacaze ${ }^{2}$

${ }^{1}$ Charles University in Prague, Faculty of Mathematics and Physics, Ke Karlovu 5, 121 16, Prague 2, Czech Republic

${ }^{2}$ CIRIMAT, ENSIACET, 5 allée Emile Monso, BP44362, 31030 Toulouse cedex 4, France. pokova@karlov.mff.cuni.cz

\begin{abstract}
Aluminium and its alloys belong to the most widely used metallic materials for industrial applications. One of the possible casting methods is twin-roll casting which produces sheets with high solid solution supersaturation. Decomposition of this supersaturated material during heat treatment was studied in aluminium alloys from the AW-3003 series - one standard grade and the other modified by addition of zirconium. Characterization by differential thermal analysis and observations by electron microscopy revealed that precipitation of $\alpha-A I M n F e S i$ phase occurred in two steps around 360 and $450{ }^{\circ} \mathrm{C}$ in twin-roll cast sheets, firstly on subgrain boundaries and afterwards also within the grains. In cold-rolled sheets, precipitates formed directly within the grains. The zirconium addition shifts recrystallization to higher annealing temperatures in the cold-rolled $\mathrm{Zr}$-containing alloy.
\end{abstract}

Keywords: Aluminium alloys, AW-3003, TEM, precipitation, $\alpha-\mathrm{AlMnFeSi}$

\section{Acknowledgment}

This work was financially supported by a project of The Czech Science Foundation GAČR P107-12-0921. M. P. would also like to acknowledge support of student grants SVV-2012-265303 and GAUK 92210 and a scholarship from the French embassy.

\section{References:}

[1] Y. BIROL: Analysis of macro segregation in twin-roll cast aluminium strips via solidification curves. Journal of Alloys and Compounds 486 (2009) 168-172.

[2] Y. J. LI, A. M. F. MUGGERUD, A. OLSEN, T. FURU: Precipitation of partially coherent $\alpha-\mathrm{Al}(\mathrm{Mn}, \mathrm{Fe}) \mathrm{Si}$ dispersoids and their strengthening effect in AA 3003 alloy. Acta Materialia 60 (2012) 1004-1014.

[3] D. T. L. ALEXANDER, A. L. GREER: Solid-state intermetallic phase transformation in 3XXX aluminium alloys. Acta Materialia 50 (2002) 2571-2583.

[4] M. KARLÍK, T. MÁNIK, H. LAUSCHMAN: Influence of Si and Fe on the distribution of intermetallic compounds in twin-roll cast Al-Mn-Zr alloys. Journal of Alloys and Compounds 515 (2012) 108-113.

[5] N. A. BELOV, D. G. ESKIN, A. A. ASKENOV: Multicomponent Phase Diagrams: Application for Commercial Aluminum Alloys, ELSEVIER (2005).

[6] M. CIESLAR, M. SLÁMOVÁ, M. HÁJEK, J. VESELÝ: Effect of Thermomechanical Pretreatment on Mechanical Properties of Modified Al-Mn-Fe-Si Based Alloys. Materials Science Forum Vols. 567-568 (2008) pp. 325328.

[7] M. DEHMAS, P. WEISBECKER, G. GDIER, P. ARCHABAULT, E. AEBY-GAUTIER: Experimental study of phase transformation in 3003 aluminium alloys during heating by in situ high energy synchrotron radiation. Journal of Alloys and Compounds 400 (2005) 116-124.

[8] M. SlÁmOVÁ, A. KUBOŠOVÁ, J. POLITELlO, M. CIESLAR: Effect of annealing on microstructure and properties of twin-roll-cast Al-Mn alloys with different copper content. International Journal of Materials Research 100 (2009) 428-432.

[9] M. POKOVÁ, M. CIESLAR, M. SLÁMOVÁ: The influence of dispersoids on the recrystallization of aluminium alloys. International Journal of Materials Research 100 (2009) 391-394.

[10] H.-W. HUANG, B.-L. OU: Evolution of precipitation during different homogenization treatments in a 3003 aluminum alloy. Materials and Design 30 (2009) 2685-2692.

[11] M. CIESLAR, M. SLÁMOVÁ, J. UHLÍŘ, CH. COUPEAU, J. BONNEVILLE: Effect of composition and work hardening on solid solution decomposition in twin-roll cast Al-Mn sheets. Kovové Materiály 45 (2007) 91-98.

[12] K. S. VECCHIO, D. B. WILLIAMS: Convergent beam electron diffraction study of $\mathrm{Al}_{3} \mathrm{Zr}$ in Al-Zr and Al-LiZr alloys. Acta Metallurgica 35 (1987) 2959-2970.

[13] E. NES, H. BILLDAL: Non-equilibrium solidification of hyperperitectic Al-Zr alloys. Acta Metallurgica 25 (1977) 1031-1037. 
[14] K. E. KNIPLING, D. C. DUNAND, D. N. SEIDMAN: Precipitation evolution in Al-Zr and Al-Zr-Ti alloys during aging at 450-600 ${ }^{\circ} \mathrm{C}$. Acta Materialia 56 (2008) 1182-1195.

[15] M. CIESLAR: EBSD studium rozdělení disperzních částic v nerovnovážně utuhnutých hliníkových slitinách. Metalografie : metody a postupy 1 (2010) 120-128, Adin, Prešov.

[16] M. POKOVÁ, M. CIESLAR, J. LACAZE: The Influence of Silicon Content on Recrystallization of twin-roll cast Aluminum Alloys for Heat Exchangers. Acta Physica Polonica A (2012) in press.

[17] J. E. HATCH: Aluminum. Properties and Physical Metallurgy. ASM, Ohio (1984).

[18] E. NES, S. SLEVOLDEN: Mechanical properties of new strip-cast AlMnZr alloys. Aluminium 55 (1979) 398400.

[19] M. POKOVÁ, M. CIESLAR, J. LACAZE: The Influence of Pre-deformation on Minority Phases Precipitation in Modified AW-3003 Aluminium. Metal 2012 Conference Proceedings (2012) 73-78.

[20] H. WEILAND, S. CHEONG: The Role of Zirconium Additions in Recrystallization of Aluminium Alloys. Materials Science Forum 558-559 (2007) 383-387.

[21] Z. JIA, G. HU, B. FORBORD, J.K. SOLBERG: Enhancement of recrystallization resistance of Al-Zr-Mn by two-step precipitation annealing. Materials Science and Engineering A 483-484 (2008) 195-198. 